Research Article

\title{
Comparison of Chemical Composition and Bioactivities of Essential Oils from Fresh and Dry Rhizomes of Zingiber zerumbet (L.) Smith
}

\author{
Minyi Tian, ${ }^{1}$ Xianghuan Wu, ${ }^{1}$ Yi Hong, ${ }^{1}$ Huijuan Wang, ${ }^{1}$ Guodong Deng, ${ }^{1}$ \\ and Ying Zhou $\mathbb{i}^{1,2}$ \\ ${ }^{1}$ Key Laboratory of Plant Resource Conservation and Germplasm Innovation in Mountainous Region (Ministry of Education), \\ Collaborative Innovation Center for Mountain Ecology \& Agro-Bioengineering (CICMEAB), College of Life Sciences, \\ Institute of Agro-bioengineering, Guizhou University, Guiyang 550025, China \\ ${ }^{2}$ College of Pharmacy, Guizhou University of Traditional Chinese Medicine, Guiyang 550025, China
}

Correspondence should be addressed to Ying Zhou; yingzhou71@yeah.net

Received 19 October 2019; Accepted 13 December 2019; Published 11 February 2020

Academic Editor: Serena Rinaldo

Copyright (c) 2020 Minyi Tian et al. This is an open access article distributed under the Creative Commons Attribution License, which permits unrestricted use, distribution, and reproduction in any medium, provided the original work is properly cited.

The chemical constituents and the antioxidant, antimicrobial, and cytotoxic activities of fresh rhizome essential oil (FR-EO) and dry rhizome essential oil (DR-EO) of Zingiber zerumbet (L.) Smith obtained from Southwest China were compared. Zerumbone was the predominant component in both FR-EO and DR-EO (75.0\% and 41.9\%, respectively). FR-EO, DR-EO, and zerumbone were all demonstrated to have significant antimicrobial capacity against Staphylococcus aureus, Bacillus subtilis, Escherichia coli, and Proteus vulgaris, with minimum inhibitory concentration (MIC) ranging from 31.25 to $156.25 \mu \mathrm{g} / \mathrm{mL}$ and minimum bactericidal concentration (MBC) ranging from 62.50 to $625.00 \mu \mathrm{g} / \mathrm{mL}$. Zerumbone showed the strongest antimicrobial potential against all tested microorganisms compared with the fresh and dry rhizome essential oils. FR-EO was found to be more active than DR-EO against Staphylococcus aureus, Bacillus subtilis, Escherichia coli, and Proteus vulgaris. FR-EO, DR-EO, and zerumbone all showed significant cytotoxic activity against K562, PC-3, and A549 human tumor cell lines in a time- and concentration-dependent manner. Zerumbone exhibited the strongest antiproliferative activity against all tested human tumor cell lines with an $\mathrm{IC}_{50}$ of $4.21-11.09 \mu \mathrm{g} / \mathrm{mL}$ for $72 \mathrm{~h}$ incubation, as compared with the fresh and dry rhizome oils. The cytotoxic activity of FR-EO $\left(\mathrm{IC}_{50}: 10.48-14.51 \mu \mathrm{g} / \mathrm{mL}\right.$ for $\left.72 \mathrm{~h}\right)$ was found to be significantly higher $(p<0.05)$ than that of DR-EO (IC ${ }_{50}: 13.83-33.24 \mu \mathrm{g} / \mathrm{mL}$ for $72 \mathrm{~h}$ ). FR-EO, DR-EO, and zerumbone exhibited selective cytotoxic activity to tumor cells, with a significantly low cytotoxicity to normal cells (MRC-5, $\mathrm{IC}_{50}: 56.98-147.29 \mu \mathrm{g} / \mathrm{mL}$ ). However, FR-EO, DR-EO, and zerumbone all exhibited weak free-radicalscavenging activity according to DPPH and ABTS analysis. The findings highlighted in this study show that FR-EO provides appreciably higher content of the bioactive compound, zerumbone, and has higher antimicrobial and cytotoxic properties than DR-EO. Thus, fresh $Z$. zerumbet rhizome should be preferred in cosmetic, food, and pharmaceutical applications.

\section{Introduction}

The genus Zingiber includes about 141 species and is an important source of essential oil that is widely used in the perfume, cosmetic, and pharmaceutical industries [1-3]. Zingiber zerumbet (L.) Smith is an aromatic and tuberose plant of this genus and is commonly known as hong qiu jiang in China. Z. zerumbet has received great interest from scientists for its spice and medicinal values $[4,5]$. It is mainly distributed in tropical and subtropical regions including Sri Lanka, Nepal, Bangladesh, Malaysia, India, and Southwest China [6]. It is a food and medicinal plant with great cultivation potential because of its low planting costs [7]. Both fresh and dry rhizomes of $Z$. zerumbet are widely used for spice, beverage, and medicinal purposes [6,8]. Traditionally, its rhizomes are used to treat cold, cough, fever, stomach cramps, flatulence, colic pain, swelling, loss of appetite, inflammation, leprosy, sore throat, bacterial infections, 
allergies, and skin diseases [7, 9]. In China, Z. zerumbet rhizome is an edible vegetable and is used as a traditional Chinese medicine for the treatment of abdominal pain and diarrhea.

Z. zerumbet rhizome oil is used in perfumes and has been studied extensively because of its high medicinal value [10]. The chemical constituents of $Z$. zerumbet rhizome essential oil from India, Malaysia, Indonesia, Bangladesh, Reunion Island, Fiji, Vietnam, Philippines, Thailand, Polynesia Islands, and Japan have been studied, and the results indicate that the chemical constituents of rhizome essential oil varied according to geographical location $[4,9,11-27]$. The $Z$. zerumbet rhizome oil is a mixture of terpenes and contains zerumbone as the major constituent [4, 12-14]. The zerumbone and $Z$. zerumbet rhizome oil have been demonstrated to have a variety of pharmacological activities, including chemopreventive [10], chemotherapeutic [10], antiproliferative [12], antinociceptive [22], antimicrobial $[12,28]$, antitumor [28, 29], antihypersensitivity [30], antioxidant $[30,31]$, antisecretory [31], and anti-inflammatory $[10,32,33]$ properties. To our knowledge, the chemical constituents and pharmacological activities of the Z. zerumbet rhizome volatile oil from Southwest China have not been reported.

Aromatic herbs are sensitive to drying processes, which can lead to the loss of biological activity [34]. In the previous literature, the chemical constituents of $Z$. zerumbet fresh or dried rhizome essential oils were studied; the results indicate that the zerumbone content in the fresh rhizome essential oil from different geographical locations varied from 8.1 to $84.8 \%[4,9,12-24]$ and the zerumbone content of the dry rhizome oil from different geographical locations varied between 1.2 and 35.5\% [25-27]. To our knowledge, the effect of drying on the chemical constituents and pharmacological activities of the volatile oil of $Z$. zerumbet rhizome has not been reported. Hence, this study was designed to compare the chemical composition and antioxidant, antimicrobial, and cytotoxic activities of fresh and dry $Z$. zerumbet rhizome essential oils. At the same time, the zerumbone, as a major bioactive constituent, was purified and compared with the bioactivities of volatile oils from fresh and dry rhizomes.

\section{Materials and Methods}

2.1. Plant Material. Fresh Z. zerumbet rhizomes were collected from Guangxi Province, China, in September 2017. A portion of the fresh rhizomes was left to dry in a laboratory air-ventilated oven dryer at a temperature of $40^{\circ} \mathrm{C}$ for $72 \mathrm{~h}$. The identity of the species was confirmed by Prof. Shenghua Wei of Guizhou University of Chinese Medicine. A voucher specimen (no. 1994) was deposited at Guizhou Engineering Center for Innovative Traditional Chinese Medicine and Ethnic Medicine, Guizhou University.

2.2. Essential Oils' Extraction. Fresh and dry Z. zerumbet rhizomes were cut into pieces and separately placed in a
Clevenger-type apparatus and submitted to hydrodistillation $(5 \mathrm{~h})$. Essential oils were dried over anhydrous $\mathrm{Na}_{2} \mathrm{SO}_{4}$, filtered, and stored in amber bottles at $4^{\circ} \mathrm{C}$.

2.3. Chromatographic Analysis. The GC-FID analysis was carried out with an Agilent 6890 gas chromatograph (GC) system coupled to a flame-ionization detector (FID) and equipped with a HP-5MS capillary column $(60 \mathrm{~m} \times 0.25 \mathrm{~mm} \times 0.25 \mu \mathrm{m}$ film thickness). The injection volume was $1 \mu \mathrm{L}$ (split ratio at $1: 100$ ) with helium as the carrier gas (flow rate: $1 \mathrm{~mL} / \mathrm{min}$ ). Oven temperature was as follows: $46^{\circ} \mathrm{C}(2 \mathrm{~min}), 3^{\circ} \mathrm{C} / \mathrm{min}$ to $190^{\circ} \mathrm{C}(48 \mathrm{~min})$, and $15^{\circ} \mathrm{C} /$ $\min$ to $310^{\circ} \mathrm{C}(8 \mathrm{~min})$. The GC-MS analysis was carried out with an Agilent 6890 GC system fitted with an Agilent 5975C MS and a HP-5MS fused silica column. GC parameters were as described above. MS was set to EI mode of $70 \mathrm{eV}$ with mass range $(\mathrm{m} / z 29$ to 500). The percentage of chemical component was calculated by the peak area normalization method. The experimental retention index was calculated by injecting a series of $n$-alkanes $\left(\mathrm{C}_{9}-\mathrm{C}_{18}\right)$. The constituents of essential oils were identified by comparison with retention index and mass spectral data in the NIST 14 and Wiley 275 databases.

2.4. Isolation and Identification of Zerumbone. Zerumbone was isolated from the essential oil of fresh rhizomes using the recrystallization method. Fresh rhizome essential oil $(5 \mathrm{~g})$ was dissolved in hexane $(10 \mathrm{~mL})$ and crystallized in a refrigerator at $-20^{\circ} \mathrm{C}$ for $30 \mathrm{~min}$ and then filtered. Recrystallization in hexane at $-20^{\circ} \mathrm{C}$ for $30 \mathrm{~min}$ and then filtration gave a white crystalline compound. Highperformance liquid chromatography (HPLC) was used to confirm the purity of the isolated compound (purity $>99.0 \%$ ). The white crystals were identified as zerumbone based on a range of detection methods (EI-MS, ${ }^{1} \mathrm{H}$ NMR, and $\left.{ }^{13} \mathrm{C} N M R\right)$. EI-MS $m / z$ (\%): $218[\mathrm{M}+], 203,189,175,163,150,135$ (100), 121, 107, 96, 79, 67, 53, 41. ${ }^{1} \mathrm{H} \mathrm{NMR}\left(\mathrm{CDCl}_{3}, 400 \mathrm{MHz}\right), \delta$ : 0.99 (3H, s, H-15), 1.13 (3H, s, H-14), 1.46 (3H, s, H-12), 1.72 (3H, s, H-13), 1.75-1.88 (1H, m, H-1), 2.12-2.30 (4H, m, H-1, H-4, H-5), 2.30-2.43 (1H, m, H-5), 5.18 (1H, bd, $J=15.1 \mathrm{~Hz}$, $\mathrm{H}-2), 5.78(1 \mathrm{H}, \mathrm{d}, J=16.4 \mathrm{~Hz}, \mathrm{H}-10), 5.89(1 \mathrm{H}, \mathrm{d}, J=16.4 \mathrm{~Hz}$, $\mathrm{H}-9), 5.92-5.96$ (1H, m, H-6); ${ }^{13} \mathrm{C} \mathrm{NMR}\left(\mathrm{CDCl}_{3}, 100 \mathrm{MHz}\right), \delta$ : 11.8 (C-13), 15.3 (C-12), 24.3(C-15), 24.5 (C-5), 29.5 (C-14), 37.9 (C-11), 39.5 (C-4), 42.4 (C-1), 125.0 (C-2), 127.2 (C-9), 136.3 (C-3), 137.9 (C-7), 148.9 (C-6), 160.7 (C-10), 204.3 (C$8)$. The white crystals were identified as zerumbone by comparison with the reported spectral data [4, 35].

2.5. Antioxidant Activity. The 1,1-diphenyl-2-picrylhydrazyl (DPPH) free-radical-scavenging capacity of fresh and dry rhizome oils and zerumbone was determined according to the method reported previously [36] with minor modification. Butylated hydroxytoluene (BHT) and ascorbic acid were used as positive controls. Various concentrations of oils and zerumbone solution $(1 \mathrm{~mL})$ were mixed with $\mathrm{DPPH}$ methanol solution $(0.1 \mathrm{mM}, 1 \mathrm{~mL})$ and allowed to stand at 
$37^{\circ} \mathrm{C}$ for $30 \mathrm{~min}$. The absorbance of the samples was measured with a spectrophotometer at $517 \mathrm{~nm}$.

The 2,2' -azino-bis-3-ethylbenzthiazoline-6-sulphonic acid (ABTS) radical-scavenging capacity of oils and zerumbone was determined according to the method reported by Re et al. [37] with marginal modifications. ABTS solution was generated by reacting $7 \mathrm{mM}$ ABTS solution with $2.45 \mathrm{mM} \mathrm{K}_{2} \mathrm{~S}_{2} \mathrm{O}_{8}$; the mixture was then allowed to stand at $37^{\circ} \mathrm{C}$ for $16 \mathrm{~h}$. Before experiments, ABTS was diluted with methanol to obtain an ABTS solution with an absorbance of $0.70 \pm 0.02$ at $734 \mathrm{~nm}$. The ABTS solution $(4 \mathrm{~mL})$ was added to various concentrations of sample solution $(0.4 \mathrm{~mL})$, and then, the mixture was incubated at $37^{\circ} \mathrm{C}$ for $10 \mathrm{~min}$ in the dark. The results are expressed using the $\mathrm{IC}_{50}$ value and ascorbic acid equivalent antioxidant capacity (AEAC) value. All measurements were repeated three times.

2.6. Antimicrobial Activity. Antimicrobial tests were performed with seven microbial strains of Staphylococcus aureus (ATCC 6538P), Enterococcus faecalis (ATCC 29212), Pseudomonas aeruginosa (CMCC (B) 10104), Bacillus subtilis (CMCC (B) 63501), Escherichia coli (ATCC 25922), Proteus vulgaris (CMCC (B) 49027), and Candida albicans (CMCC (F) 98001). Antimicrobial activities of FR-EO, DR$\mathrm{EO}$, and zerumbone were evaluated by using the disc agar diffusion assay reported previously [38] with minor modification. FR-EO, DR-EO, and zerumbone solutions were diluted with ethyl acetate $(100 \mathrm{mg} / \mathrm{mL})$. Filter paper discs (diameter $6 \mathrm{~mm}$ ) containing oils and zerumbone solution $(20 \mu \mathrm{L})$ were incubated at $37^{\circ} \mathrm{C}$ for $24 \mathrm{~h}$, and the inhibition zone diameter (including the $6 \mathrm{~mm}$ disk) was recorded. The MIC and MBC values of FR-EO, DR-EO, and zerumbone were evaluated by the broth microdilution assay described previously [39] with slight modification. The FR-EO, DR$\mathrm{EO}$, and zerumbone were initially diluted in DMSO and later in Mueller-Hinton broth or Sabouraud dextrose broth. The tested sample solution of twofold dilution $(100 \mu \mathrm{L})$ was transferred into each well. The inoculum was added to all wells. The final concentration of the bacterial cells in the wells was approximately $5 \times 10^{5} \mathrm{CFU} / \mathrm{mL}$. The 96 -well plates were incubated for $24 \mathrm{~h}$ at $37^{\circ} \mathrm{C}$, and then, $10 \mu \mathrm{L}$ of resazurin aqueous solution $(0.01 \%)$ was added to the 96 -well plates as an indicator of microbial growth by detecting the reduction of blue dye resazurin to pink resorufin. The 96-well plates were incubated at $37^{\circ} \mathrm{C}$ for $2 \mathrm{~h}$ in the dark. The MIC was defined as the lowest concentration of the sample when the resazurin color changed. To obtain the MBC value, $10 \mu \mathrm{L}$ samples were obtained from the wells (no color change) and subcultured in agar plates, and the MBC was determined as the lowest concentration without any microbial growth after $24 \mathrm{~h}$ at $37^{\circ} \mathrm{C}[40]$. Each test was repeated in triplicate.

2.7. Cytotoxic Activity. Human prostatic carcinoma (PC-3), leukemic (K562), lung cancer (A549), and fetal lung fibroblasts (MRC-5) cell lines were maintained in RPMI 1640 medium ( $2 \mathrm{mM}$ glutamine, $10 \%$ fetal bovine serum,
$100 \mathrm{U} / \mathrm{mL}$ penicillin, and $100 \mathrm{U} / \mathrm{mL}$ streptomycin) and incubated in a humidified incubator at $37^{\circ} \mathrm{C}$ with $5 \% \mathrm{CO}_{2}$ atmosphere. The cytotoxic activity was evaluated by MTT assay with slight modification [41]. The cells were seeded at a density of $5 \times 10^{3}$ cells per well in $80 \mu \mathrm{L}$ of culture medium and incubated for $24 \mathrm{~h}$ before treatment. The FR-EO, DR$\mathrm{EO}$, and zerumbone were dissolved in DMSO and then serially double diluted with the medium. The diluted sample solution $(20 \mu \mathrm{L})$ was added to each well and incubated for 24 , 48 , and $72 \mathrm{~h}$. The medium was then removed, and $10 \mu \mathrm{L}$ of MTT solution ( $5 \mathrm{mg} / \mathrm{mL}$ in PBS) was added to the wells and cultured for $4 \mathrm{~h}$. Formazan crystals in each well were dissolved by the addition of DMSO $(150 \mu \mathrm{L})$. A microplate spectrophotometer was used to measure and record the optical density at $490 \mathrm{~nm}$. The results of cytotoxic activity were expressed using the $\mathrm{IC}_{50}$ value. Each test was repeated in triplicate.

2.8. Statistical Analysis. The results of the tests were repeated in triplicate and expressed as the means \pm SD. SPSS software (version 19.0) was used for statistical analysis. Data were compared by one-way analysis of variance (ANOVA) using Tukey's multiple range tests, which was significant at $p<0.05$.

\section{Results and Discussion}

3.1. Chemical Composition. Hydrodistillation of fresh and dry $Z$. zerumbet rhizomes yielded essential oils in $0.65 \%$ and $0.39 \%(w / w)$ of fresh weight, respectively. In the present study, crystals were observed during hydrodistillation. Zerumbone crystals were uniformly mixed with rhizome oils and were analyzed by using GC-FID/MS (Table 1). Thirty-six compounds were identified, accounting for $98.9 \%$ of FR-EO. The major component was zerumbone $(75.0 \%)$, followed by $\alpha$-humulene $(6.5 \%)$, humulene oxide I (3.8\%), camphene (3.3\%), humulene oxide II $(2.7 \%)$, camphor $(1.3 \%)$, caryophyllene oxide (1.3\%), and 1,8-cineole (1.2\%) (Figure 1). Thirty-six compounds representing $98.8 \%$ of DR-EO were identified, containing mainly zerumbone (41.9\%), followed by $\alpha$-humulene $(29.4 \%)$, humulene oxide I (6.0\%), humulene oxide II (3.9\%), camphene (3.9\%), $\beta$-caryophyllene $(2.5 \%)$, camphor $(2.4 \%)$, caryophyllene oxide $(2.1 \%)$, and 1,8 -cineole (1.6\%) (Figure 2). The chemical constituents of $Z$. zerumbet rhizome oil from different geographic regions were found to vary $[4,9,11-27]$. To our knowledge, the chemical constituents of the $Z$. zerumbet rhizome volatile oil from Southwest China have not been reported. Most early studies showed that zerumbone was the main constituent. The zerumbone content in FR-EO from different geographical locations varied from 8.1 to $84.8 \%$ [4, 9, 12-24]. In DR-EO from different geographical locations, the zerumbone content varied between 1.2 and $35.5 \%$ [25-27]. Zerumbone is a highly volatile compound with a unique odor [42]. Our work was undertaken to compare chemical constituents of essential oils of fresh and dry Z. zerumbet rhizomes from a 
TABLE 1: Chemical composition of Z. zerumbet FR-EO and DR-EO.

\begin{tabular}{|c|c|c|c|c|c|}
\hline \multirow{2}{*}{ Compound $^{\mathrm{a}}$} & \multirow{2}{*}{$\mathrm{RI}^{\mathrm{b}}$} & \multirow{2}{*}{$\mathrm{RI}^{\mathrm{c}}$} & \multicolumn{2}{|c|}{$\%$ area } & \multirow{2}{*}{ Identification $^{\mathrm{d}}$} \\
\hline & & & DR-EO & FR-EO & \\
\hline Tricyclene & 926 & 925 & 0.1 & 0.1 & MS, RI \\
\hline$\alpha$-Pinene & 937 & 937 & 1.0 & 0.8 & MS, RI \\
\hline Camphene & 952 & 952 & 3.9 & 3.3 & MS, RI \\
\hline Sabinene & 976 & 974 & $\operatorname{tr}$ & $\operatorname{tr}$ & MS, RI \\
\hline$\beta$-Pinene & 980 & 979 & $\operatorname{tr}$ & $\operatorname{tr}$ & MS, RI \\
\hline$\beta$-Myrcene & 992 & 991 & 0.1 & 0.1 & MS, RI \\
\hline$\alpha$-Phellandrene & 1007 & 1005 & 0.1 & 0.1 & MS, RI \\
\hline$\delta$-3-Carene & 1013 & 1011 & 0.5 & 0.2 & MS, RI \\
\hline p-Cymene & 1027 & 1023 & 0.1 & 0.1 & MS, RI \\
\hline 1,8-Cineole & 1034 & 1032 & 1.6 & 1.2 & MS, RI \\
\hline$\gamma$-Terpinene & 1062 & 1060 & $\operatorname{tr}$ & $\operatorname{tr}$ & MS, RI \\
\hline Fenchone & 1092 & 1096 & 0.1 & 0.1 & MS, RI \\
\hline Linalool & 1101 & 1099 & 0.6 & 0.3 & MS, RI \\
\hline Camphor & 1149 & 1145 & 2.4 & 1.3 & MS, RI \\
\hline 1-Borneol & 1170 & 1167 & 0.2 & 0.1 & MS, RI \\
\hline 4-Terpineol & 1180 & 1182 & 0.1 & 0.1 & MS, RI \\
\hline$\alpha$-Terpineol & 1193 & 1189 & 0.2 & 0.1 & MS, RI \\
\hline Verbenone & 1212 & 1204 & $\operatorname{tr}$ & $\operatorname{tr}$ & MS, RI \\
\hline 1-Bornyl acetate & 1291 & 1284 & 0.1 & $\operatorname{tr}$ & MS, RI \\
\hline Isobornyl acetate & 1294 & 1286 & 0.1 & $\operatorname{tr}$ & MS, RI \\
\hline Myrtenyl acetate & 1329 & 1327 & $\operatorname{tr}$ & $\operatorname{tr}$ & MS, RI \\
\hline$\alpha$-Copaene & 1378 & 1376 & $\operatorname{tr}$ & $\operatorname{tr}$ & MS, RI \\
\hline$\beta$-Elemene & 1394 & 1391 & 0.1 & $\operatorname{tr}$ & MS, RI \\
\hline$\alpha$-Gurjunene & 1417 & 1409 & 0.1 & $\operatorname{tr}$ & MS, RI \\
\hline$\beta$-Caryophyllen & 1429 & 1419 & 2.5 & 0.4 & MS, RI \\
\hline$\alpha$-Bergamotene & 1440 & 1435 & $\operatorname{tr}$ & $\operatorname{tr}$ & MS, RI \\
\hline$\alpha$-Humulene & 1467 & 1454 & 29.4 & 6.5 & MS, RI \\
\hline$\delta$-Cadinene & 1534 & 1524 & 0.1 & $\operatorname{tr}$ & MS, RI \\
\hline Hedycaryol & 1560 & 1559 & 0.1 & $\operatorname{tr}$ & MS, RI \\
\hline$d$-Nerolidol & 1568 & 1564 & 0.1 & 0.1 & MS, RI \\
\hline Caryophyllene oxide & 1599 & 1581 & 2.1 & 1.3 & MS, RI \\
\hline Humulene oxide I & 1614 & 1596 & 6.0 & 3.8 & MS, RI \\
\hline Humulene oxide II & 1625 & 1606 & 3.9 & 2.7 & MS, RI \\
\hline allo-Aromadendrene epoxide & 1657 & 1639 & 1.0 & 0.8 & MS, RI \\
\hline$\beta$-Eudesmol & 1663 & 1649 & 0.3 & 0.4 & MS, RI \\
\hline Zerumbone & 1735 & 1732 & 41.9 & 75.0 & MS, RI \\
\hline Monoterpene hydrocarbons (\%) & & & 5.8 & 4.7 & \\
\hline Oxygenated monoterpenes (\%) & & & 5.2 & 3.2 & \\
\hline Sesquiterpene hydrocarbons (\%) & & & 32.2 & 6.9 & \\
\hline Oxygenated sesquiterpenes (\%) & & & 55.4 & 84.1 & \\
\hline Total $(\%)$ & & & 98.8 & 98.9 & \\
\hline Yield (W/W) (\%) & & & 0.39 & 0.65 & \\
\hline
\end{tabular}

${ }^{\mathrm{a}}$ Compounds are listed in order of their elution from a HP-5MS column. ${ }^{\mathrm{b}}$ Retention index on the HP-5MS column, calculated using homologous series of $\mathrm{C}_{9}-\mathrm{C}_{18}$ alkanes. ${ }^{\mathrm{c}}$ Retention index from NIST 14 and Wiley 275 mass spectral databases. ${ }^{\mathrm{d}}$ Identification: MS, based on comparison with Wiley 275 and NIST 14 MS databases; RI, based on comparison of calculated RI with those reported in Wiley 275 and NIST 14 databases. $\operatorname{tr}$ : $\operatorname{trace}(\operatorname{trace}<0.1 \%)$.

single geographical location. The results showed that the content of zerumbone was higher in fresh rhizome oil than in dry rhizome oil. The loss of zerumbone during oven drying processing steps of the rhizome might be attributed to its high volatility. The FR-EO yield $(0.65 \%)$ of $Z$. zerumbet was higher than the DR-EO yield (0.39\%). Oven drying significantly decreased the content of zerumbone and resulted in a low extraction yield of DR-EO. Zerumbone was isolated from fresh rhizome essential oil by recrystallization and identified by spectroscopic analysis. HPLC was used to verify the purity of zerumbone (purity $>99.0 \%$ ). This method of extracting zerumbone from fresh rhizome essential oil using only recrystallization is a relatively simple and effective method.

3.2. Antioxidant Activity. The antioxidant ability of oils and zerumbone was determined based on DPPH and ABTS assays using ascorbic acid and BHT as positive control (Table 2). The $\mathrm{IC}_{50}$ values of DPPH free-radical-scavenging capacity were $17416.04 \pm 3274.95,32385.39 \pm 5628.23$, and $90293.12 \pm 3529.38 \mu \mathrm{g} / \mathrm{mL}$ for DR-EO, FR-EO, and zerumbone, respectively, which were much higher than those of BHT $(29.25 \pm 1.87 \mu \mathrm{g} / \mathrm{mL})$ and ascorbic acid 


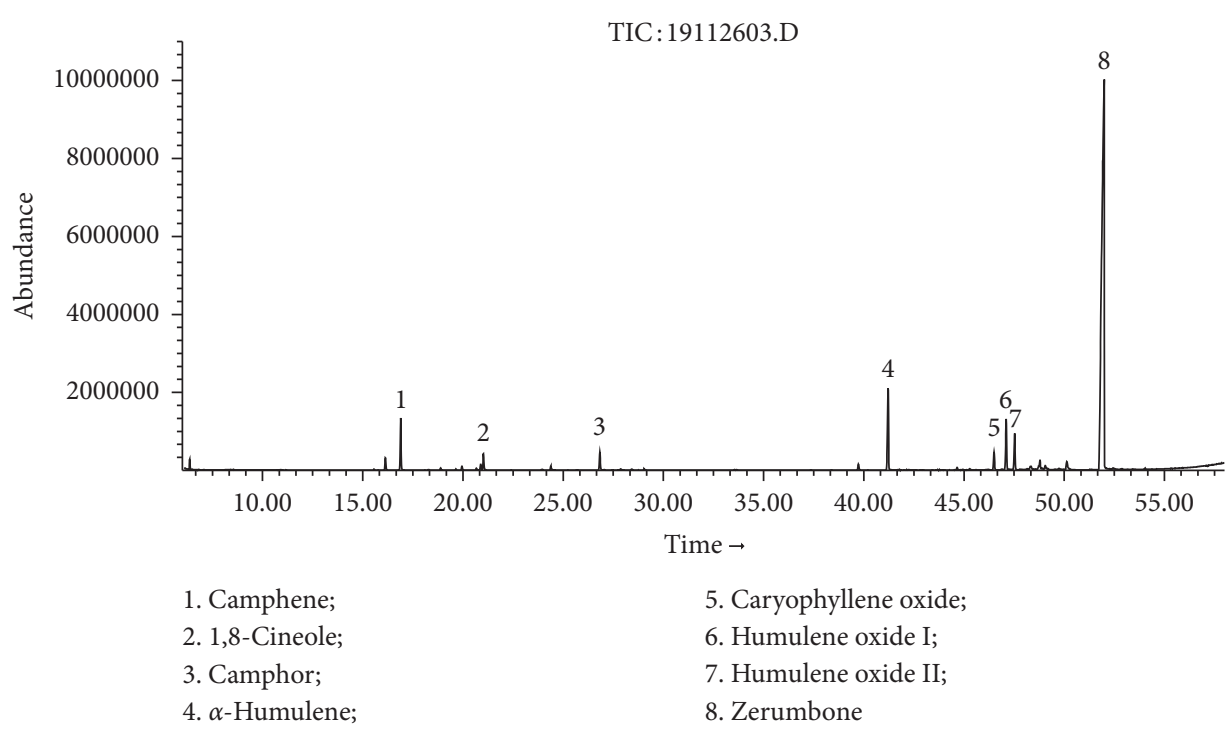

FIGURE 1: GC-MS chromatogram of Z. zerumbet FR-EO.

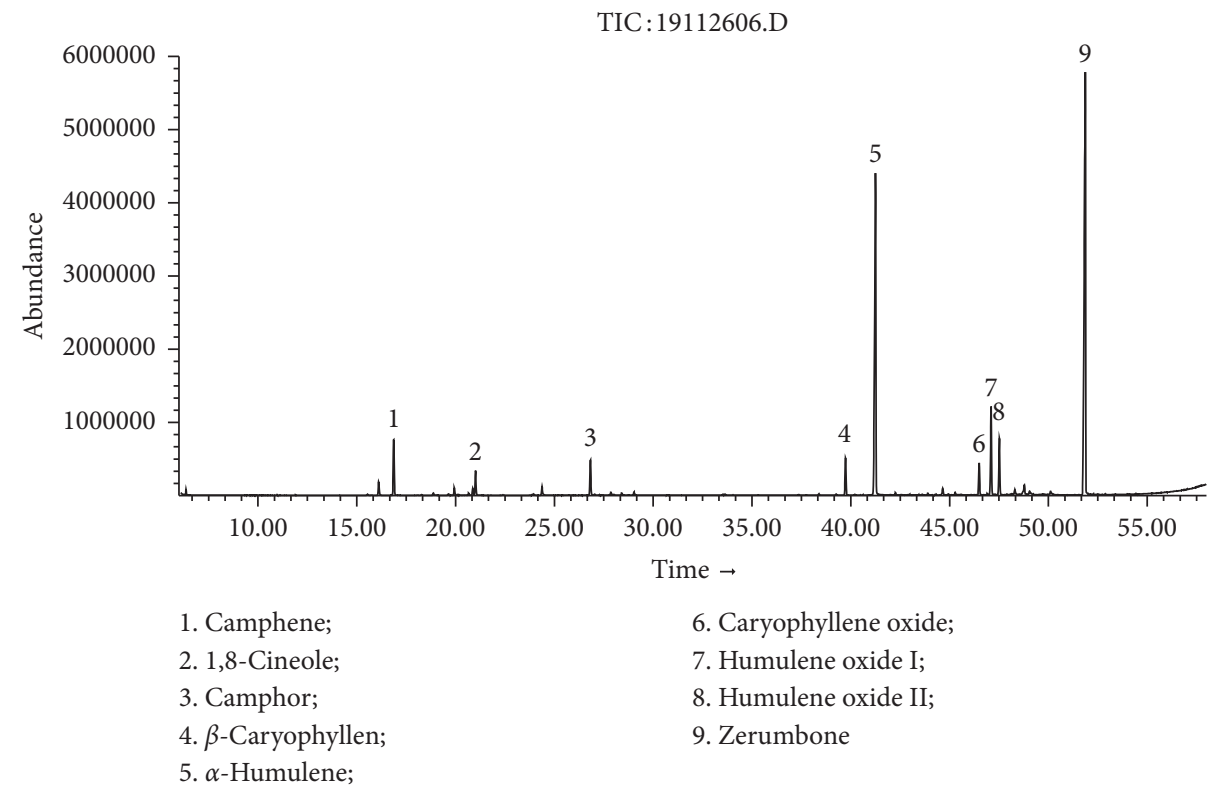

FIGURE 2: GC-MS chromatogram of Z. zerumbet DR-EO.

TABLe 2: Antioxidant ability of FR-EO and DR-EO of Z. zerumbet and zerumbone.

\begin{tabular}{lcccc}
\hline Sample & \multicolumn{2}{c}{ DPPH } & & \multicolumn{2}{c}{ ABTS } \\
& $\mathrm{IC}_{50}(\mu \mathrm{g} / \mathrm{mL})^{\mathrm{a}}$ & $\mathrm{AEAC}^{\mathrm{a}}(\mathrm{mg} / 100 \mathrm{~g})^{\mathrm{b}}$ & $\mathrm{IC}_{50}(\mu \mathrm{g} / \mathrm{mL})^{\mathrm{a}}$ & $\mathrm{AEAC}(\mathrm{mg} / 100 \mathrm{~g})^{\mathrm{b}}$ \\
\hline DR-EO & $17416.04 \pm 3274.95$ & 9.01 & $2884.67 \pm 232.71$ & 74.90 \\
FR-EO & $32385.39 \pm 5628.23$ & 4.85 & $2926.68 \pm 104.28$ & 73.82 \\
Zerumbone & $90293.12 \pm 3529.38$ & 1.74 & $10840.13 \pm 938.35$ & \\
BHT $^{c}$ & $29.25 \pm 1.87$ & & $7.47 \pm 0.12$ & \\
Ascorbic acid $^{c}$ & $1.57 \pm 0.23$ & & $2.16 \pm 0.43$ & \\
\hline
\end{tabular}

${ }^{\mathrm{a}} \mathrm{IC}_{50}$ : the concentration of sample that affords a $50 \%$ reduction in the assay, expressed as the means $\pm \mathrm{SD}$ of triplicate experiments. ${ }^{\mathrm{b}} \mathrm{AEAC}$ (ascorbic acid equivalent antioxidant capacity $)=\left(\mathrm{IC}_{50(\mathrm{AA})} / \mathrm{IC}_{50(\text { Sample })}\right) \times 10^{5} .{ }^{\mathrm{c}} \mathrm{BHT}$ and ascorbic acid as positive control.

$(1.57 \pm 0.23 \mu \mathrm{g} / \mathrm{mL})$. In the determination of ABTS radicalscavenging capacity, the $\mathrm{IC}_{50}$ values of DR-EO $(2884.67 \pm$ $232.71 \mu \mathrm{g} / \mathrm{mL})$, FR-EO $(2926.68 \pm 104.28 \mu \mathrm{g} / \mathrm{mL})$, and zerumbone $(10840.13 \pm 938.35 \mu \mathrm{g} / \mathrm{mL})$ were much higher than those of BHT $(7.47 \pm 0.12 \mu \mathrm{g} / \mathrm{mL})$ and ascorbic acid $(2.16 \pm 0.43 \mu \mathrm{g} / \mathrm{mL})$. In the DPPH and ABTS assays, the 
TABLE 3: Diameter of the inhibition zones of Z. zerumbet FR-EO, DR-EO, and zerumbone using the agar disc diffusion method.

\begin{tabular}{|c|c|c|c|c|}
\hline \multirow{2}{*}{ Microorganisms } & \multicolumn{4}{|c|}{ Diameter of the inhibition zones $(\mathrm{mm})^{\mathrm{a}}$} \\
\hline & FR-EO & DR-EO & Zerumbone & Streptomycin \\
\hline \multicolumn{5}{|l|}{ Gram positive } \\
\hline Enterococcus faecalis ATCC 29212 & $10.41 \pm 2.31$ & $9.31 \pm 0.69$ & $10.00 \pm 0.68$ & $9.74 \pm 0.96$ \\
\hline Staphylococcus aureus ATCC 6538P & $14.54 \pm 3.78$ & $12.31 \pm 1.22$ & $15.72 \pm 2.42$ & $19.69 \pm 1.63$ \\
\hline Bacillus subtilis CMCC (B) 63501 & $9.99 \pm 1.86$ & $8.55 \pm 1.89$ & $9.48 \pm 1.96$ & $9.38 \pm 1.21$ \\
\hline \multicolumn{5}{|l|}{ Gram negative } \\
\hline Pseudomonas aeruginosa CMCC (B) 10104 & $8.34 \pm 0.70$ & $8.23 \pm 1.17$ & $9.71 \pm 0.97$ & $8.36 \pm 1.08$ \\
\hline Escherichia coli ATCC 25922 & $9.36 \pm 1.98$ & $9.79 \pm 1.68$ & $10.85 \pm 0.83$ & $11.37 \pm 0.88$ \\
\hline Proteus vulgaris CMCC (B) 49027 & $11.06 \pm 1.01$ & $10.29 \pm 1.03$ & $11.71 \pm 1.55$ & $17.13 \pm 2.14$ \\
\hline \multicolumn{5}{|l|}{ Fungus } \\
\hline Candida albicans CMCC (F) 98001 & $10.93 \pm 1.13$ & $9.31 \pm 1.80$ & $11.31 \pm 0.83$ & $\mathrm{Na}$ \\
\hline
\end{tabular}

${ }^{a}$ The diameter of the inhibition zones $(\mathrm{mm})$ were measured including the diameter of the disk $(6 \mathrm{~mm})$. The sample solution: FR-EO, DR-EO, and zerumbone were diluted with ethyl acetate, at a concentration of $100 \mathrm{mg} / \mathrm{mL}$ (tested volume: $20 \mu \mathrm{L}$ ); positive control: streptomycin (tested volume: $20 \mu \mathrm{L}, 100 \mu \mathrm{g} / \mathrm{mL}$ ).

TABLE 4: MIC and MBC values of $Z$. zerumbet FR-EO, DR-EO, and zerumbone using microdilution assay.

\begin{tabular}{|c|c|c|c|c|c|c|c|c|}
\hline \multirow{3}{*}{ Microorganism } & \multicolumn{8}{|c|}{$\mathrm{MIC}$ and $\mathrm{MBC}(\mu \mathrm{g} / \mathrm{mL})^{\mathrm{a}}$} \\
\hline & \multicolumn{2}{|c|}{ FR-EO } & \multicolumn{2}{|c|}{ DR-EO } & \multicolumn{2}{|c|}{ Zerumbone } & \multicolumn{2}{|c|}{ Streptomycin } \\
\hline & MIC & MBC & MIC & MBC & MIC & $\mathrm{MBC}$ & MIC & $\mathrm{MBC}$ \\
\hline \multicolumn{9}{|l|}{ Gram positive } \\
\hline E. faecalis ATCC 29212 & 1250.00 & 1250.00 & 1250.00 & 1250.00 & 250.00 & 250.00 & 0.20 & 0.78 \\
\hline S. aureus ATCC 6538P & 78.13 & 156.25 & 156.25 & 156.25 & 31.25 & 62.50 & 0.78 & 0.78 \\
\hline B. subtilis CMCC (B) 63501 & 78.13 & 156.25 & 156.25 & 312.50 & 62.50 & 125.00 & 0.10 & 0.20 \\
\hline \multicolumn{9}{|l|}{ Gram negative } \\
\hline P. aeruginosa CMCC (B)10104 & 312.50 & 625.00 & 312.50 & 625.00 & 250.00 & 250.00 & 3.13 & 12.50 \\
\hline E. coli ATCC 25922 & 156.25 & 312.25 & 156.25 & 625.00 & 62.50 & 62.50 & 3.13 & 6.25 \\
\hline P. vulgaris CMCC (B) 49027 & 78.13 & 156.25 & 156.25 & 312.50 & 62.50 & 62.50 & 0.20 & 0.39 \\
\hline \multicolumn{9}{|l|}{ Fungus } \\
\hline C. albicans CMCC (F) 98001 & 312.50 & 2500.00 & 312.50 & 2500.00 & 31.25 & 250.00 & $\mathrm{Na}$ & $\mathrm{Na}$ \\
\hline
\end{tabular}

${ }^{a} \mathrm{MIC}$ : minimal inhibitory concentration; MBC: minimal bactericidal concentration; streptomycin as positive control.

greater the $\mathrm{IC}_{50}$ value, the weaker the ability to scavenge free radicals. Zerumbone exhibited significantly lower radical-scavenging activity than the fresh and dry rhizome essential oils $(p<0.05)$. The DR-EO showed more radicalscavenging activity but was nonsignificant $(p>0.05)$ compared to the FR-EO. The DR-EO, FR-EO, and zerumbone showed weak radical-scavenging capacity according to DPPH and ABTS assays. However, Hemn et al. [30] reported that zerumbone was an effective antioxidant that inhibits free-radical production in the prevention and treatment of atherosclerosis in vivo. The DPPH and ABTS assays can be used to assess the ability to scavenge free radicals but are not suitable for assessing lipid peroxidation inhibition efficiency [43]. Different methods of assessment of antioxidant capacity in vitro and in vivo may result in inconsistent results.

3.3. Antimicrobial Activity. The antimicrobial ability of fresh and dry rhizome essential oils and zerumbone was qualitatively determined based on the disc agar diffusion assay and quantitatively assessed by the broth microdilution assay. The results are presented in Table 3 and Table 4. The fresh and dry rhizome essential oils and zerumbone showed varying degrees of antimicrobial potential. Zerumbone was the most effective, as compared with FR-EO and DR-EO, against all tested strains; the diameter of inhibition zones ranged from 9.48 to $15.72 \mathrm{~mm}$ and showed minimal MIC (31.25-250.00 $\mu \mathrm{g} / \mathrm{mL})$ and MBC $(62.50-250.00 \mu \mathrm{g} / \mathrm{mL})$. The MIC and MBC values of FR-EO were the same as those of DR-EO against E. faecalis, $P$. aeruginosa, and $C$. albicans, but FR-EO exhibited higher activity than DR-EO against $S$. aureus, B. subtilis, E. coli, and $P$. vulgaris, with the diameter of inhibition zones (9.36-14.54 mm), MIC (78.13-156.25 $\mu \mathrm{g} / \mathrm{mL})$, and MBC $(156.25-312.25 \mu \mathrm{g} / \mathrm{mL})$. The diameter of inhibition zones, $\mathrm{MIC}$, and MBC for DR-EO against all tested strains ranged from 8.23 to $12.31 \mathrm{~mm}, 156.25$ to $1250.00 \mu \mathrm{g} / \mathrm{mL}$, and 156.25 to $2500.00 \mu \mathrm{g} / \mathrm{mL}$, respectively. Zerumbone was reported to exhibit significant to moderate antimicrobial activity and was discovered to be an important antimicrobial active compound $[10,44,45]$. Hence, the antimicrobial capacity of $Z$. zerumbet rhizome oil might be associated with the content of zerumbone. Oven drying significantly reduced the content of zerumbone, which might be responsible for the decrease in the antimicrobial ability of $Z$. zerumbet rhizome essential oil.

3.4. Cytotoxic Activity. The antiproliferation activity of fresh and dry rhizome oils and zerumbone was evaluated against K562, PC-3, and A549 human tumor cell lines and MRC-5 
TABLE 5: Cytotoxic properties of FR-EO and DR-EO of Z. zerumbet and zerumbone.

\begin{tabular}{|c|c|c|c|c|c|}
\hline \multirow{2}{*}{ Sample } & \multirow{2}{*}{ Incubation time $(\mathrm{h})$} & \multicolumn{4}{|c|}{$\mathrm{IC}_{50}(\mu \mathrm{g} / \mathrm{mL})^{\mathrm{a}}$} \\
\hline & & $\mathrm{A} 549^{\mathrm{b}}$ & $\mathrm{PC}-3^{\mathrm{c}}$ & $\mathrm{K} 562^{\mathrm{d}}$ & $\mathrm{MRC}-5^{\mathrm{e}}$ \\
\hline \multirow{3}{*}{ FR-EO } & 24 & $44.88 \pm 1.21$ & $53.32 \pm 1.34$ & $35.73 \pm 1.72$ & $159.47 \pm 9.34$ \\
\hline & 48 & $38.64 \pm 1.03$ & $21.45 \pm 1.18$ & $13.73 \pm 0.54$ & $133.82 \pm 5.97$ \\
\hline & 72 & $14.51 \pm 0.61$ & $11.23 \pm 0.53$ & $10.48 \pm 0.95$ & $106.21 \pm 7.34$ \\
\hline \multirow{3}{*}{ DR-EO } & 24 & $68.06 \pm 1.09$ & $77.45 \pm 0.46$ & $41.79 \pm 1.18$ & $216.99 \pm 8.27$ \\
\hline & 48 & $56.14 \pm 1.76$ & $43.90 \pm 1.65$ & $17.22 \pm 0.51$ & $164.68 \pm 2.71$ \\
\hline & 72 & $33.24 \pm 0.53$ & $13.83 \pm 0.59$ & $14.96 \pm 1.18$ & $147.29 \pm 4.30$ \\
\hline \multirow{3}{*}{ Zerumbone } & 24 & $22.40 \pm 1.80$ & $30.78 \pm 1.31$ & $10.08 \pm 0.61$ & $117.96 \pm 5.67$ \\
\hline & 48 & $19.00 \pm 0.72$ & $14.30 \pm 1.84$ & $6.24 \pm 1.05$ & $79.79 \pm 3.17$ \\
\hline & 72 & $11.09 \pm 0.39$ & $7.66 \pm 0.68$ & $4.21 \pm 0.84$ & $56.98 \pm 1.82$ \\
\hline \multirow{3}{*}{ Cisplatin $^{\mathrm{f}}$} & 24 & $5.17 \pm 0.44$ & $40.64 \pm 1.38$ & $20.36 \pm 0.62$ & $14.58 \pm 0.91$ \\
\hline & 48 & $3.38 \pm 0.61$ & $7.64 \pm 0.39$ & $11.53 \pm 0.91$ & $5.29 \pm 0.67$ \\
\hline & 72 & $1.91 \pm 0.87$ & $2.16 \pm 0.67$ & $5.10 \pm 0.54$ & $2.99 \pm 0.49$ \\
\hline
\end{tabular}

${ }^{a} \mathrm{IC}_{50}$ : the sample concentration reduced cells growth by $50 \%$ (after 24-, 48-, and 72-hour incubation), expressed as the mean \pm SD of triplicate experiments. ${ }^{b}$ Human lung cancer cell line. ${ }^{c}$ Human prostatic carcinoma cell line. ${ }^{d}$ Human leukemic cell line. ${ }^{e}$ Human fetal lung fibroblasts cell line. ${ }^{f}$ Cisplatin as positive control.

normal human cell line by MTT assay (Table 5). FR-EO, DR$\mathrm{EO}$, and zerumbone exhibited significant cytotoxicity against all tested tumor cell lines in a time- and concentration-dependent manner. The cytotoxic capacity against tumor cell lines of the oils and zerumbone were, from strongest to weakest: zerumbone $>$ FR-EO $>$ DR-EO, with statistical significance at $p<0.05$. The zerumbone reduced the proliferation of $\mathrm{A} 549\left(\mathrm{IC}_{50}=11.09 \pm 0.39 \mu \mathrm{g} / \mathrm{mL}\right), \mathrm{PC}-3$ $\left(\mathrm{IC}_{50}=7.66 \pm 0.68 \mu \mathrm{g} / \mathrm{mL}\right)$, and $\mathrm{K} 562\left(\mathrm{IC}_{50}=4.21 \pm 0.84 \mu \mathrm{g} /\right.$ $\mathrm{mL}$ ) cell lines after $72 \mathrm{~h}$ incubation and showed more cytotoxicity against K562 compared to the positive control (cisplatin). The FR-EO affected the proliferation of A549, $\mathrm{PC}-3$, and $\mathrm{K} 562$ cell lines for $72 \mathrm{~h}$ incubation with $\mathrm{IC}_{50}$ values $(10.48-14.51 \mu \mathrm{g} / \mathrm{mL})$ and was more effective than DR$\mathrm{EO}$, which had $\mathrm{IC}_{50}$ values in the range 13.83 to $33.24 \mu \mathrm{g} / \mathrm{mL}$ for $72 \mathrm{~h}$ incubation $(p<0.05)$. The $\mathrm{IC}_{50}$ values of FR-EO, DR-EO, and zerumbone against K562, PC-3, and A549 tumor cells were significantly lower compared to those against the normal cell line (MRC-5, IC $50: 56.98-147.29 \mu \mathrm{g} /$ $\mathrm{mL}$ for $72 \mathrm{~h}$ ), with statistical significance at $p<0.05$. Recent studies have shown that zerumbone possessed significant cytotoxic activity against lung cancer [12], colon cancer [46], leukemia [47], ovarian cancer [48], skin cancer [49], liver cancer [50, 51], and breast cancer [52]. Zerumbone from $Z$. zerumbet has been found to be a highly active anticancer natural product [10]. In previous studies, zerumbone had no considerable cytotoxic effect on normal mammalian cells (Vero) up to $100 \mu \mathrm{g} / \mathrm{mL}$ after $48 \mathrm{~h}$ incubation [53]. Zerumbone exhibited selective cytotoxic activity to human tumor cell lines, with a significantly lower cytotoxicity to human normal cell line than to tumor cells. The second main compound in both FR-EO and DR-EO was $\alpha$-humulene ( $10.8 \%$ and $28.5 \%$, respectively). The $\alpha$-humulene, a structural analogue lacking only the carbonyl group in zerumbone, did not exhibit anticancer ability [54, 55]. Therefore, drying process negatively affected the cytotoxic capacity of rhizome essential oil suggesting that zerumbone, mostly lost during the process, was mainly responsible of cytotoxic activity.

\section{Conclusion}

To our knowledge, this is the first comparison of the chemical composition and antioxidant, antimicrobial, and cytotoxic activities of $Z$. zerumbet fresh and dry rhizome essential oils. Thirty-six compounds of FR-EO and DR-EO were identified by using GC-FID/MS, and the major component was zerumbone $(75.0 \%$ and $41.9 \%$, respectively). In addition to their low antioxidant activity, FR-EO, DR-EO, and zerumbone demonstrated significant antimicrobial capacity against $S$. aureus, B. subtilis, E. coli, and P. vulgaris and significant cytotoxic activity against A549, K562, and PC-3 cell lines. Oven drying had a significant effect on the chemical constituents and on the antimicrobial and cytotoxic capacity of the rhizome oil. From GC-MS data, it was clear that the content of zerumbone in DR-EO was considerably less than that in FR-EO. The results of antimicrobial and cytotoxic analysis clearly showed that FR-EO was more effective than DR-EO. Oven drying significantly reduced the content of zerumbone, which was responsible for the decline in antibacterial and cytotoxic properties of rhizome. The fresh $Z$. zerumbet rhizome was found to have more bioactive compound, zerumbone, and showed stronger antimicrobial and cytotoxic properties than the dry rhizome. Thus, fresh $Z$. zerumbet rhizomes should be preferred in cosmetics, food, and pharmaceutical applications.

\section{Data Availability}

The data used to support the findings of this study are available from the corresponding author upon request.

\section{Conflicts of Interest}

The authors declare that they have no conflicts of interest.

\section{Acknowledgments}

The authors are grateful for the financial support grant from National Key R\&D Program of China (2018YFC1708100); 
Guizhou Science and Technology Program (Qian Ke He Zhi Cheng (2017) 2850, Qian Ke He Ping Tai Ren Cai (2018) 5781-49, and Qian Ke He (2016) Zhi Cheng 2909); and Guizhou Medical Products Administration (DB52/YC122013).

\section{Supplementary Materials}

Figure S1: pure zerumbone crystals. Figure S2: mass spectrum spectral data of zerumbone. Figure S3: ${ }^{1} \mathrm{H}$ NMR spectral data of zerumbone. Figure S4: ${ }^{13} \mathrm{C}$ NMR spectral data of zerumbone. Figure S5: the purity test of zerumbone using an HPLC system. (Supplementary Materials)

\section{References}

[1] B. Sabulal, M. Dan, J. J. Anil et al., "Caryophyllene-rich rhizome oil of Zingiber nimmonii from South India: chemical characterization and antimicrobial activity," Phytochemistry, vol. 67, no. 22, pp. 2469-2473, 2006.

[2] J. W. Tan, D. A. Israf, and C. L. Tham, "Major bioactive compounds in essential oils extracted from the rhizomes of Zingiber zerumbet (L) Smith: a mini-review on the anti-allergic and immunomodulatory properties," Frontiers in Pharmacol, vol. 9, p. 652, 2018.

[3] M. Y. Tian, Y. Hong, X. H. Wu, M. Zhang, B. Lin, and Y. Zhou, "Chemical constituents and cytotoxic activities of essential oils from the flowers, leaves and stems of Zingiber striolatum diels," Records of Natural Products, vol. 14, no. 2, pp. 144-149, 2020.

[4] S. Baby, M. Dan, A. R. M. Thaha et al., "High content of zerumbone in volatile oils of Zingiber zerumbet from southern India and Malaysia," Flavour and Fragrance Journal, vol. 24, no. 6, pp. 301-308, 2009.

[5] N. J. Yob, S. M. Jofrry, M. M. Affandi, L. K. Teh, M. Z. Salleh, and Z. A. Zakaria, "Zingiber zerumbet (L.) Smith: a review of its ethnomedicinal, chemical, and pharmacological uses," Evidence-Based Complementary and Alternative Medicine, vol. 2011, Article ID 543216, 12 pages, 2011.

[6] H. S. Rahman, A. Rasedee, S. K. Yeap et al., "Biomedical Properties of a Natural Dietary Plant Metabolite, Zerumbone, in Cancer Therapy and Chemoprevention Trials," Biomed Research International, vol. 2014, Article ID 920742, 20 pages, 2014.

[7] A. Y. Koga, F. L. Beltrame, and A. V. Pereira, "Several aspects of Zingiber zerumbet: a review," Revista Brasileira de Farmacognosia, vol. 26, no. 3, pp. 385-391, 2016.

[8] Tushar, S. Basak, G. C. Sarma, and L. Rangan, "Ethnomedical uses of Zingiberaceous plants of Northeast India," Journal of Ethnopharmacology, vol. 132, no. 1, pp. 286-296, 2010.

[9] V. S. Rana, V. Ahluwalia, N. A. Shakil, and L. Prasad, "Essential oil composition, antifungal, and seedling growth inhibitory effects of zerumbone from Zingiber zerumbet Smith," Journal of Essential Oil Research, vol. 29, no. 4, pp. 320-329, 2017.

[10] Y. P. Singh, S. Girisa, K. Banik et al., "Potential application of zerumbone in the prevention and therapy of chronic human diseases," Journal of Functional Foods, vol. 53, pp. 248-258, 2019.

[11] I. Batubara, I. H. Suparto, S. Sadiah, R. Matsuoka, and T. Mitsunaga, "Effect of Zingiber zerumbet essential oils and zerumbone inhalation on body weight of Sprague Dawley rat,"
Pakistan Journal of Biological Sciences, vol. 16, no. 19, pp. 1028-1033, 2013.

[12] R. C. Padalia, R. S. Verma, A. Chauhan et al., "Zingiber zerumbet (L.) Roscoe ex Sm. from northern India: potential source of zerumbone rich essential oil for antiproliferative and antibacterial applications," Industrial Crops and Products, vol. 112, pp. 749-754, 2018.

[13] N. X. Duñg, T. D. Chińh, D. D. Rañg, and P. A. Leclercq, "The constituents of the rhizome oil of Zingiber zerumbet (L.) Sm. From Vietnam," Journal of Essential Oil Research, vol. 5, no. 5, pp. 553-555, 1993.

[14] B. H. Madegowda, P. Rameshwaran, N. P. Nagaraju, and P. S. Murthy, "In-vitroMycological activity of essential oil from Zingiber zerumbet rhizomes," Journal of Essential Oil Research, vol. 28, no. 1, pp. 81-88, 2016.

[15] M. N. I. Bhuiyan, J. U. Chowdhury, and J. Begum, "Chemical investigation of the leaf and rhizome essential oils of Zingiber zerumbet (L.) Smith from Bangladesh," Bangladesh Journal of Pharmacology, vol. 4, pp. 9-12, 2009.

[16] J. Chane-Ming, R. Vera, and J.-C. Chalchat, "Chemical composition of the essential oil from rhizomes, leaves and flowers of Zingiber zerumbet Smith from Reunion Island," Journal of Essential Oil Research, vol. 15, no. 3, pp. 202-205, 2003.

[17] N. P. Damodaran and S. Dev, "Studies in sesquiterpenesXXXVII," Tetrahedron, vol. 24, no. 11, pp. 4113-4122, 1968.

[18] I. Lechat-Vahirua, P. François, C. Menut, G. Lamaty, and J.-M. Bessiere, "Aromatic plants of French Polynesia. I. Constituents of the essential oils of rhizomes of three Zingiberaceae: Zingiber zerumbet Smith, Hedychium coronarium Koenig and Etlingera cevuga Smith," Journal of Essential Oil Research, vol. 5, no. 1, pp. 55-59, 1993.

[19] S. N. A. Malek, H. Ibrahim, H. S. Lai et al., "Essential oils of Zingiber ottensii valet. and Zingiber zerumbet (L.) Sm. from Sabah, Malaysia," Malaysian Journal of Science, vol. 24, pp. 49-58, 2005.

[20] C. B. Singh, S. B. Chanu, L. Kh, N. Swapana, C. Cantrell, and S. A. Ross, "Chemical composition and biological activity of the essential oil of rhizome of Zingiber zerumbet (L.) Smith," Journal Pharmacognosy and Phytochemistry, vol. 3, no. 3, pp. 130-133, 2014.

[21] A. K. Srivastava, S. K. Srivastava, and N. C. Shah, "Essential oil composition of Zingiber zerumbet (L.) Sm. from India," Journal of Essential Oil Research, vol. 12, no. 5, pp. 595-597, 2000.

[22] M. Sulaiman, T. Tengku Mohamad, W. Shaik Mossadeq et al., "Antinociceptive activity of the essential oil of Zingiber zerumbet," Planta Medica, vol. 76, no. 02, pp. 107-112, 2010.

[23] D. Suthisut, P. G. Fields, and A. Chandrapatya, "Fumigant toxicity of essential oils from three Thai plants (Zingiberaceae) and their major compounds against Sitophilus zeamais, Tribolium castaneum and two parasitoids," Journal of Stored Products Research, vol. 47, no. 3, pp. 222-230, 2011.

[24] F. Yu, H. Harada, K. Yamasaki et al., "Isolation and functional characterization of a $\beta$-eudesmol synthase, a new sesquiterpene synthase from Zingiber zerumbet Smith," FEBS Letters, vol. 582, no. 5, pp. 565-572, 2008.

[25] D. N. Dai, T. D. Thang, L. T. M. Chau, and I. A. Ogunwande, "Chemical constituents of the root essential oils of Zingiber rubens Roxb., and Zingiber zerumbet (L. ) Smith," American Journal of Plant Sciences, vol. 4, no. 1, pp. 7-10, 2013.

[26] M. B. Oliveros and M. C. Cantoria, "Pharmacognostic studies on Zingiber zerumbet (linné) smith and its proposed variety (family Zingiberaceae)," International Journal of Crude Drug Research, vol. 20, no. 3, pp. 141-153, 1982. 
[27] N. Sutthanont, W. Choochote, B. Tuetun et al., "Chemical composition and larvicidal activity of edible plant-derived essential oils against the pyrethroid-susceptible and -resistant strains of Aedes aegypti (Diptera: Culicidae)," Journal of Vector Ecology, vol. 35, no. 1, pp. 106-115, 2010.

[28] A. B. Abdul, S. I. Abdelwahab, A. S. Al-Zubairi, M. M. Elhassan, and S. M. Murali, "Anticancer and antimicrobial activities of zerumbone from the rhizomes of Zingiber zerumbet," International Journal of Pharmacology, vol. 4, no. 4, pp. 301-304, 2008.

[29] G.-C. Huang, T.-Y. Chien, L.-G. Chen, and C.-C. Wang, "Antitumor effects of zerumbone from Zingiber zerumbet in P-388D1Cellsin vitroandin vivo," Planta Medica, vol. 71, no. 3, pp. 219-224, 2005.

[30] H. O. Hemn, M. M. Noordin, H. S. Rahman, H. Hazilawati, A. Zuki, and M. S. Chartrand, "Antihypercholesterolemic and antioxidant efficacies of zerumbone on the formation, development, and establishment of atherosclerosis in cholesterol-fed rabbits," Drug Design, Development and Therapy, vol. 9, pp. 4173-4208, 2015.

[31] H. M. A. Sidahmed, N. M. Hashim, M. A. Abdulla et al., "Antisecretory, gastroprotective, antioxidant and anti-helicobcter pylori activity of zerumbone from Zingiber Zerumbet (L.) Smith," PLoS One, vol. 10, no. 3, Article ID e0121060, 2015.

[32] M. N. Somchit, J. H. Mak, A. Ahmad Bustamam et al., "Zerumbone isolated from Zingiber zerumbet inhibits inflammation and pain in rats," Journal of Medicinal Plants Research, vol. 6, no. 2, pp. 177-180, 2012.

[33] Z. A. Zakaria, A. S. Mohamad, M. S. Ahmad et al., "Preliminary analysis of the anti-inflammatory activity of essential oils of Zingiber zerumbet," Biological Research for Nursing, vol. 13, no. 4, pp. 425-432, 2011.

[34] A. Ghasemi Pirbalouti, E. Mahdad, and L. Craker, "Effects of drying methods on qualitative and quantitative properties of essential oil of two basil landraces," Food Chemistry, vol. 141, no. 3, pp. 2440-2449, 2013.

[35] T. Kitayama, T. Okamoto, R. K. Hill et al., "Chemistry of zerumbone. 1. Simplified isolation, conjugate addition reactions, and a unique ring contracting transannular reaction of its dibromide," The Journal of Organic Chemistry, vol. 64, no. 8, pp. 2667-2672, 1999.

[36] Y. Y. Lim, T. T. Lim, and J. J. Tee, "Antioxidant properties of several tropical fruits: a comparative study," Food Chemistry, vol. 103, no. 3, pp. 1003-1008, 2007.

[37] R. Re, N. Pellegrini, A. Proteggente, A. Pannala, M. Yang, and C. Rice-Evans, "Antioxidant activity applying an improved ABTS radical cation decolorization assay," Free Radical Biology and Medicine, vol. 26, no. 9-10, pp. 1231-1237, 1999.

[38] H.-Y. Zhang, Y. Gao, and P.-X. Lai, "Chemical composition, antioxidant, antimicrobial and cytotoxic activities of essential oil from Premna microphylla Turczaninow," Molecules, vol. 22, no. 3, p. 381, 2017.

[39] J. Eloff, "A sensitive and quick microplate method to determine the minimal inhibitory concentration of plant extracts for bacteria," Planta Medica, vol. 64, no. 8, pp. 711-713, 1998.

[40] M. Mzid, S. Ben Khedir, M. Ben Salem, W. Regaieg, and T. Rebai, "Antioxidant and antimicrobial activities of ethanol and aqueous extracts from Urtica urens," Pharmaceutical Biology, vol. 55, no. 1, pp. 775-781, 2017.

[41] T. Mosmann, "Rapid colorimetric assay for cellular growth and survival: application to proliferation and cytotoxicity assays," Journal of Immunological Methods, vol. 65, no. 1-2, pp. 55-63, 1983.

[42] K. Ogawa, T. Miyoshi, T. Kitayama, and M. Ito, "Locomotorreducing effects and structural characteristics of inhaled zerumbone and tetrahydrozerumbone derivatives," Biological and Pharmaceutical Bulletin, vol. 37, no. 9, pp. 1559-1563, 2014.

[43] E. Niki, "Assessment of antioxidant capacity in vitro and in vivo," Free Radical Biology and Medicine, vol. 49, no. 4, pp. 503-515, 2010.

[44] S. C. Santosh Kumar, P. Srinivas, P. S. Negi, and B. K. Bettadaiah, "Antibacterial and antimutagenic activities of novel zerumbone analogues," Food Chemistry, vol. 141, no. 2, pp. 1097-1103, 2013.

[45] H. N. Vishwanatha, P. Niraguna Babu, B. S. Gowrishankar, and S. B. Shridhar, "Antimicrobial activity of zerumbone from Zingiber zerumbet against Staphylococcus epidermidis and Aspergillus spp," International Journal of Applied Biology and Pharmacetical Technology, vol. 3, pp. 40-43, 2012.

[46] S. Yodkeeree, B. Sung, P. Limtrakul, and B. B. Aggarwal, "Zerumbone enhances TRAIL-induced apoptosis through the induction of death receptors in human colon cancer cells: evidence for an essential role of reactive oxygen species," Cancer Research, vol. 69, no. 16, pp. 6581-6589, 2009.

[47] M. Xian, K. Ito, T. Nakazato et al., "Zerumbone, a bioactive sesquiterpene, induces $\mathrm{G} 2 / \mathrm{M}$ cell cycle arrest and apoptosis in leukemia cells via a Fas- and mitochondria-mediated pathway," Cancer Science, vol. 98, no. 1, pp. 118-126, 2007.

[48] S. I. Abdelwahab, A. B. Abdul, Z. N. M. Zain, and A. H. A. Hadi, "Zerumbone inhibits interleukin- 6 and induces apoptosis and cell cycle arrest in ovarian and cervical cancer cells," International Immunopharmacology, vol. 12, no. 4, pp. 594-602, 2012.

[49] A. Murakami, T. Tanaka, J.-Y. Lee et al., “Zerumbone, a sesquiterpene in subtropical ginger, suppresses skin tumor initiation and promotion stages in ICR mice," International Journal of Cancer, vol. 110, no. 4, pp. 481-490, 2004.

[50] S. A. Sakinah, S. T. Handayani, and L. P. Hawariah, "Zerumbone induced apoptosis in liver cancer cells via modulation of Bax/Bcl-2 ratio," Cancer Cell International, vol. 7, no. 1, p. 4, 2007.

[51] M. M. E. Taha, A. B. Abdul, R. Abdullah, T. A. T. Ibrahim, S. I. Abdelwahab, and S. Mohan, "Potential chemoprevention of diethylnitrosamine-initiated and 2-acetylaminofluorenepromoted hepatocarcinogenesis by zerumbone from the rhizomes of the subtropical ginger (Zingiber zerumbet)," ChemicoBiological Interactions, vol. 186, no. 3, pp. 295-305, 2010.

[52] A. Sehrawat, J. A. Arlotti, A. Murakami, and S. V. Singh, "Zerumbone causes Bax- and Bak-mediated apoptosis in human breast cancer cells and inhibits orthotopic xenograft growth in vivo," Breast Cancer Research and Treatment, vol. 136, no. 2, pp. 429-441, 2012.

[53] T. M. da Silva, C. D. Pinheiro, P. P. Orlandi, C. C. Pinheiro, and G. S. Pontes, "Zerumbone from Zingiber zerumbet (L.) smith: a potential prophylactic and therapeutic agent against the cariogenic bacterium Streptococcus mutans," BMC Complementary and Alternative Medicine, vol. 18, no. 1, p. 301, 2018.

[54] A. Murakami, M. Takahashi, S. Jiwajinda, K. Koshimizu, and H. Ohigashi, "Identification of zerumbone in Zingiber zerumbet Smith as a potent inhibitor of 12-O-Tetradecanoylphorbol-13-acetate-induced epstein-Barr virus Activation," Bioscience, Biotechnology, and Biochemistry, vol. 63, no. 10, pp. 1811-1812, 1999.

[55] A. Murakami, D. Takahashi, T. Kinoshita et al., "Zerumbone, a Southeast Asian ginger sesquiterpene, markedly suppresses free radical generation, proinflammatory protein production, and cancer cell proliferation accompanied by apoptosis: the alpha,beta-unsaturated carbonyl group is a prerequisite," Carcinogenesis, vol. 23, no. 5, pp. 795-802, 2002. 